\title{
Laboratory module design for Biology Students: A Systematic review
}

\author{
Wahyu Kusumawardani ${ }^{1}$, Muzzazinah ${ }^{2}$, Murni Ramli ${ }^{3}$ * \\ Check for updates \\ Master program of Biology Education, Faculty of Teacher Training and Education, Universitas Sebelas \\ Maret, Indonesia \\ ${ }^{1}$ wahyukusumawardani@student.uns.ac.id *, ${ }^{2}$ yayin_pbio@fkip.uns.ac.id, ${ }^{3}$ mramlim@staff.uns.ac.id \\ * Corresponding author
}

\begin{tabular}{ll}
\hline ARTICLE INFO \\
\hline Article history \\
Received & September 20, 2019 \\
Revised & April 16, 2020 \\
Accepted & May 07, 2020
\end{tabular}

Keyword:

Biology

Development

Laboratory

Module

\begin{abstract}
Module design for students' laboratory activities plays an important role in the effective implementation of scientific investigation in the laboratory. The purpose of this review is to examine the types, topics, competencies, and approaches to develop laboratory module for biology students. The review of the literature was conducted systematically. Eighteen research articles were selected from 41 articles published within 2009 and 2019. The systematic review followed 5 steps. The research articles were searched using Google Scholar's online database and then traced back from the relevant international and national journals. The articles collected were selected by two reviewers who rated the quality. The results of the analysis showed that the laboratory modules are designed using the following basis: online, research, quantitative skills, inquiry, and traditional. The biology topics focused are Genetics, Ecology, Phylogenetics, Biochemistry, Molecular Biology, Evolution, Biotechnology, and Tissue Culture. The methods used for laboratory module development by Indonesian researchers are 4D, ADDIE, R \& D, Dick \& Carey, and Borg \& Gall, while international researchers generally do not specify the name of the method used. Generally, the need analysis which focuses on the novelty of the developed concept is conducted in the beginning. It continues with module designing, validation, implementation, and response survey from the students as the module users.
\end{abstract}

This is an open access article under the CC-BY-SA license.

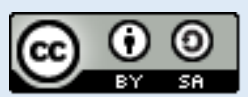

\section{Introduction}

Module is a learning instrument containing materials, methods, definitions, terminologies, and evaluation procedures that is designed interestingly to achieve expected competencies. Laboratory module is one of the supporting modules for research- oriented activities which replaces or complement the traditional "cookbook" practicum modules in various disciplines (Siritunga et al., 2011).
Laboratory modules in higher education are commonly provided by lecturers and contain a sort of experiment procedures that students simply follow. For courses that demand laboratory activities, generally in the early semester, Biology students use laboratory modules consisting of some experiments which already have results (Peteroy-Kelly, 2010). The low number of research-oriented laboratory modules that contain scientifically tested research techniques and procedures and the 
lack of students' research experience during their study can affect the quality of students' scientific skills in the laboratory (Siritunga et al., 2011).

An alternative that can be taken to boost students' research skills and quality of experiment activities in the laboratory is to formulate the qualified and researchbased module. The module that is developed from a research on particular material can help students construct interactive individual experience, understand their involvement during the research process, and apply knowledge in formulating scientific questions that lead to research activities (Goff et al., 2017; Howard \& Miskowski, 2005). The laboratory modules are generally designed to include some material components and student activities which can be adopted by cognate study programs in higher education. The designed laboratory modules are expected to facilitate students in developing research mindset through a process of scientific reasoning along with improving the students' conceptual understanding. In addition, the use of modules is expected to be able to nurture students' abilities for their career.

A great number of designs and materials for laboratory modules have been used in universities. The selection of laboratory module design will certainly affect the development of students' skills and knowledge. The importance of module design in the implementation of laboratory activities, especially in biology, has encouraged the researchers to examine the diversity of laboratory module designs that have been used by biology students. This article will identify and analyze research on biology modules that have been used and published in international and national journals. The purpose of writing the article is to find the types of module design, topics, the competencies being empowered, and the approaches used in formulating the biology laboratory modules.

The research problems constructed in the article are: (1) What are the types of biology laboratory module designs that have been studied? (2) What are the biology topics or themes of laboratory modules covered? (3) What are the effects of using different kinds of laboratory module designs on students' competencies? (4) What are the approaches for developing biology laboratory modules that are often used by Indonesian and international researchers?

\section{Method}

This study followed the steps of systematic review approach adopted from (Khan, Kunz, Kleijnen, \& Antes, 2003) which consists of 5 steps: 1) Developing a framework for formulating review questions, 2) Identifying relevant research, 3) Assessing the quality of research being reviewed, 4) Writing the results of the study, and 5) Analyzing and interpreting the results of the study.

The first step was determining four questions that would be investigated structurally: 1) Types of biology modules that have been studied, 2) Biology laboratory module themes, 3) Competencies are focused in the modules, and 4) Approaches for designing the modules.

The second step was determining the keywords search, the inclusion and exclusion criteria that would be used as the basis for searching the research articles. For the inclusion criteria, the phrase "biology laboratory modules", and the word "undergraduate" were used. The exclusion criteria limited the search on quantitative research that were published in the last ten years (2009-2019). The first search was conducted using Google scholar with the keywords "module, laboratory, biology, and undergraduate". Twenty articles in the selected relevant international journals were found and 8 articles were selected. In the second search, the keywords "biology module" and "undergraduate" were used and 5 articles were selected from 12 articles in the relevant international journals. The third search was carried out in the national journals. The selection of articles in the national journals focused on searching research-based modules in Indonesia. The keywords used were "research-based biology student modules" and 5 articles were selected from 9 articles found.

The eligibility of the eighteen articles selected were checked by two experts who assessed the quality of the research based on the research design criteria and publisher (the third step). The assessment showed that the 18 articles were eligible to be reviewed. From those articles, 13 articles were taken from international journals, four from national journals and one from international proceedings. The fourth step 
was presenting the data, and analyzing the results.

Analysis were focused on the types of module design, biology topics, competencies designated, and the module development approaches. The fifth step was interpreting and reviewing the eighteen articles

\section{Results and Discussion}

Data that presented in the table are journal identity, and information of research on laboratory modules that have been used by Biology undergraduate students. The articles that were reviewed are presented in Table 1 and Table 2.

\section{Types of laboratory module design}

The success of laboratory activities is determined by the design of the laboratory modules used. It is found that the designs of biology laboratory modules that were identified in the reviewed articles consists of five types: online-based with quantitative skills approach, research-based, inquirybased, quantitative skills-based and traditionally-based.

\subsection{Online or web-based modules}

Mathbench module is an online-based module used by biology students at Maryland University. The module contains texts, graphics, and interactive elements. The module component contains interactive programs that enable students to explore mathematical concepts in biology which focus on molecular biology (Thompson, Nelson, Marbach-Ad, Keller, \& Fagan, 2010).

\subsection{Research-based modules}

It is the most common type of module design. Modules developed based on research results contain a combination of theory and research activities which promote students understand the concrete application of the concepts being studied and help them achieve the expected competencies (Fajarwati, Kiswandianta, \& Pujiati, 2018).

Table 1. List of articles on laboratory modules developed for Biology students by international researchers

\begin{tabular}{|c|c|c|c|c|}
\hline Year & Author (s) ; (Title); Publisher & $\begin{array}{c}\text { Types of } \\
\text { module }\end{array}$ & Materials & Competencies \\
\hline 2009 & $\begin{array}{l}\text { Kären C. Nelson, Gili Marbach-Ad, } \\
\text { Katie Schneider, Katerina V. } \\
\text { Thompson, Patricia A. Shields, and } \\
\text { William F. Fagan (MathBench Biology } \\
\text { Modules Web-Based Math for All } \\
\text { Biology Undergraduates) Journal of } \\
\text { College Science Teaching }\end{array}$ & $\begin{array}{l}\text { Online or } \\
\text { web-based } \\
\text { interactive } \\
\text { module } \\
\text { (quantitative } \\
\text { approach) }\end{array}$ & Genetics & $\begin{array}{l}\text { The ability to calculate } \\
\text { probabilities, use } \\
\text { graphs, and use } \\
\text { mathematical concepts } \\
\text { in biology. }\end{array}$ \\
\hline 2010 & $\begin{array}{l}\text { Raina Robeva,* Robin Davies, } † \text { Terrell } \\
\text { Hodge, } \neq \text { and Alexander Enyedi } \\
\text { (Mathematical Biology Modules Based } \\
\text { on Modern Molecular Biology and } \\
\text { Modern Discrete Mathematics) CBE- } \\
\text { Life Sciences Education }\end{array}$ & $\begin{array}{l}\text { Skill-based } \\
\text { module } \\
\text { (quantitative) }\end{array}$ & $\begin{array}{l}\text { Molecular } \\
\text { biology and } \\
\text { phylogenetics }\end{array}$ & $\begin{array}{l}\text { Increasing interest in } \\
\text { integrating modern } \\
\text { mathematics and } \\
\text { modern biology, } \\
\text { increasing awareness } \\
\text { of the importance of } \\
\text { biomathematics in life, } \\
\text { and encouraging } \\
\text { collaboration and } \\
\text { development across } \\
\text { disciplines }\end{array}$ \\
\hline 2010 & $\begin{array}{l}\text { Katerina V. Thompson,* Ka"ren C. } \\
\text { Nelson,† Gili Marbach-Ad,** Michael } \\
\text { Keller,*and William F. Fagan† (Online } \\
\text { Interactive Teaching Modules Enhance } \\
\text { Quantitative Proficiency of } \\
\text { Introductory Biology Students) CBE- } \\
\text { Life Sciences Education }\end{array}$ & $\begin{array}{l}\text { Online-based } \\
\text { interactive } \\
\text { module } \\
\text { (quantitative } \\
\text { approach) }\end{array}$ & $\begin{array}{l}\text { Normal } \\
\text { Distribution, } \\
\text { population } \\
\text { and Scientific } \\
\text { Methods }\end{array}$ & $\begin{array}{l}\text { Quantitative biology } \\
\text { skills and concept } \\
\text { reinforcement }\end{array}$ \\
\hline 2012 & $\begin{array}{l}\text { Sara E. Brownell, Matthew J. Kloser, } \\
\text { Tadashi Fukami, and Rich Shavelson } \\
\text { (Undergraduate Biology Lab Courses: } \\
\text { Comparing the Impact of Traditionally } \\
\text { Based "Cookbook" and Authentic } \\
\text { Research-Based Courses on Student } \\
\text { Lab Experiences) Journal of College } \\
\text { Science Teaching }\end{array}$ & $\begin{array}{l}\text { Traditional } \\
\text { Module and } \\
\text { research- } \\
\text { based module }\end{array}$ & Ecology & $\begin{array}{l}\text { Formulating } \\
\text { hypotheses, analyzing } \\
\text { data, and } \\
\text { communicating results } \\
\text { in verbal and written } \\
\text { form }\end{array}$ \\
\hline
\end{tabular}




\begin{tabular}{|c|c|c|c|c|}
\hline 2012 & $\begin{array}{l}\text { Adrienne Alaie, Virginia Teller, Wei- } \\
\text { Gang Qiu (A Bioinformatics Module } \\
\text { for use in an Introductory Biology } \\
\text { Laboratory) National Association of } \\
\text { Biology Teachers }\end{array}$ & $\begin{array}{l}\text { Research- } \\
\text { based module } \\
\text { (bioinformatic } \\
\text { s) }\end{array}$ & $\begin{array}{l}\text { Gen Bank and } \\
\text { BLAST } \\
\text { program }\end{array}$ & Student performance \\
\hline 2013 & $\begin{array}{l}\text { James M. Burnette and Susan R. } \\
\text { Wessler (Transposing from the } \\
\text { Laboratory to the Classroom to } \\
\text { Generate Authentic Research } \\
\text { Experiences for Undergraduates) The } \\
\text { Genetics Society of America } \\
\text { (Education) }\end{array}$ & $\begin{array}{l}\text { Research- } \\
\text { based module }\end{array}$ & $\begin{array}{l}\text { GENOME } \\
\text { (transgenic } \\
\text { plant, PCR } \\
\text { analysis) }\end{array}$ & $\begin{array}{l}\text { Research skills \& } \\
\text { research concept }\end{array}$ \\
\hline 2014 & $\begin{array}{l}\text { Krissi M. Hewitt, Lori J. Kayes, David } \\
\text { Hubert and Adam Chouinard } \\
\text { (Investigating Issues in the Laboratory: } \\
\text { The Behavior of Red Swamp Crayfish } \\
\text { as an Invasive Species) National } \\
\text { Association of Biology Teachers }\end{array}$ & $\begin{array}{l}\text { Research- } \\
\text { based module } \\
\text { (problems) }\end{array}$ & $\begin{array}{l}\text { Invasion } \\
\text { biology, } \\
\text { animal } \\
\text { behavior, and } \\
\text { behavioral } \\
\text { ecology. }\end{array}$ & $\begin{array}{l}\text { students' perceptions } \\
\text { of their learning } \\
\text { experience }\end{array}$ \\
\hline 2014 & $\begin{array}{l}\text { Rosanna L. Robinson \& James E. } \\
\text { McDonald (Developing Skills in Second } \\
\text { Year Biological Science } \\
\text { Undergraduates) Bioscience Education }\end{array}$ & $\begin{array}{l}\text { Skill-based } \\
\text { module }\end{array}$ & Biosciences & $\begin{array}{l}\text { Project design skills, } \\
\text { literacy skills, critical } \\
\text { and creative thinking } \\
\text { skills }\end{array}$ \\
\hline 2016 & $\begin{array}{l}\text { Kathleen Hoffman, Sarah Leupen, } \\
\text { Kathy Dowell, Kerrie Kephart, and Jeff } \\
\text { Leips (Development and Assessment } \\
\text { of Modules to Integrate Quantitative } \\
\text { Skills in Introductory Biology Courses) } \\
\text { CBE-Life Sciences Education }\end{array}$ & $\begin{array}{l}\text { Skill-based } \\
\text { module } \\
\text { (quantitative) }\end{array}$ & $\begin{array}{l}\text { Ecology and } \\
\text { Evolution }\end{array}$ & $\begin{array}{l}\text { Quantitative reasoning } \\
\text { and skill }\end{array}$ \\
\hline 2017 & $\begin{array}{l}\text { Carolyn F. Weber; Microgreen Farming } \\
\text { and Nutrition (A Discovery-Based } \\
\text { Laboratory Module to Cultivate } \\
\text { Biological } \\
\text { and Information Literacy in } \\
\text { Undergraduates) National Association } \\
\text { of Biology Teachers. }\end{array}$ & $\begin{array}{l}\text { Research- } \\
\text { based module }\end{array}$ & biotechnology & $\begin{array}{l}\text { quantitative } \\
\text { skills and information } \\
\text { literacy in the context } \\
\text { of biology. }\end{array}$ \\
\hline 2018 & $\begin{array}{l}\text { Jay M, Bhatt, and Anil Kumar Challa } \\
\text { (First Year Course-Based } \\
\text { Undergraduate Research Experience } \\
\text { (CURE) Using the CRISPR/Cas9 } \\
\text { Genome Engineering Technology in } \\
\text { Zebrafish) American Society for } \\
\text { Microbiology }\end{array}$ & $\begin{array}{l}\text { Research- } \\
\text { based module }\end{array}$ & $\begin{array}{l}\text { Molecular } \\
\text { Biology }\end{array}$ & $\begin{array}{l}\text { Skills and } \\
\text { understanding of } \\
\text { laboratory work } \\
\text { principles }\end{array}$ \\
\hline 2019 & $\begin{array}{l}\text { Marta Hammerstad† Åsmund K. Røhr, } \\
\text { Hans-Petter Hersleth (A Research- } \\
\text { Inspired Biochemistry Laboratory } \\
\text { Module - Combining Expression, } \\
\text { Purification, Crystallization, Structure- } \\
\text { Solving, and Characterization of a } \\
\text { Flavodoxin-like Protein) Biochemistry } \\
\text { and Molecular Biology Education }\end{array}$ & $\begin{array}{l}\text { Research- } \\
\text { based module }\end{array}$ & $\begin{array}{l}\text { Biochemistry } \\
\text { and Biological } \\
\text { structure }\end{array}$ & Skills and knowledge \\
\hline 2019 & $\begin{array}{l}\text { Lawrence S. Blumer and Christopher } \\
\text { W. Beck (Laboratory Courses with } \\
\text { Guided-Inquiry Modules Improve } \\
\text { Scientific Reasoning and Experimental } \\
\text { Design Skills for the Least-Prepared } \\
\text { Undergraduate Students) CBE-Life } \\
\text { Sciences Education }\end{array}$ & $\begin{array}{l}\text { Guided } \\
\text { inquiry-based } \\
\text { module }\end{array}$ & Insect Ecology & $\begin{array}{l}\text { scientific reasoning } \\
\text { and experimental } \\
\text { design }\end{array}$ \\
\hline
\end{tabular}

One of the research-based modules that can be developed is bioinformatics module. Biology students need to be equipped with basic skills in computational and quantitative biology. Becoming familiar with bioinformatics will be a strength for students when they apply for a job because biologists are expected to be able to use information in the field of bioinformatics (Alaie, Teller, \& Qiu, 2012). The application of research-based modules requires biology students to be ready to meet biological issues in the real world and to make connection between science and society (Hewitt, Kayes, Hubert, \& Chouinard, 2014). 
Table 2. List of articles on laboratory modules developed for Biology students by Indonesian researchers

\begin{tabular}{|c|c|c|c|c|}
\hline Year & Author; (Title); Publisher & $\begin{array}{c}\text { Types of } \\
\text { laboratory } \\
\text { module }\end{array}$ & Materials & $\begin{array}{l}\text { Development } \\
\text { Method }\end{array}$ \\
\hline 2014 & $\begin{array}{l}\text { Umi Fitriyati, Nandang Mufti, Umie } \\
\text { Lestari (Pengembangan Modul } \\
\text { Berbasis Riset Pada Matakuliah } \\
\text { Bioteknologi /The Development of } \\
\text { Research-based Module on } \\
\text { Biotechnology Course) Jurnal } \\
\text { Pendidikan Sains }\end{array}$ & $\begin{array}{l}\text { Research- } \\
\text { based }\end{array}$ & $\begin{array}{l}\text { Biotechnology - } \\
\text { Animal tissue culture } \\
\text { techniques and } \\
\text { antiproliferative test } \\
\text { of ZnO particles } \\
\text { against breast cancer } \\
\text { cells }\end{array}$ & $\begin{array}{l}\text { Thiagarajan } \\
\text { (4D) }\end{array}$ \\
\hline 2016 & $\begin{array}{l}\text { Wasiatus Sa'diyah, Endang Suarsini, } \\
\text { Ibrohim (Pengembangan Modul } \\
\text { Bioteknologi Lingkungan Berbasis } \\
\text { Penelitian Matakuliah Bioteknologi } \\
\text { Untuk Mahasiswa S1 Universitas } \\
\text { Negeri Malang / The Development of } \\
\text { Research-based Module on } \\
\text { Environmental Biotechnology for } \\
\text { Biotechnology Undergraduate } \\
\text { Students of Universitas Negeri } \\
\text { Malang) Jurnal Pendidikan }\end{array}$ & $\begin{array}{l}\text { Research- } \\
\text { based }\end{array}$ & $\begin{array}{l}\text { Environmental } \\
\text { biotechnology in } \\
\text { reducing heavy metal } \\
\text { pollution }\end{array}$ & Borg and Gall \\
\hline 2016 & $\begin{array}{l}\text { Rizka Elan Fadilah, Mohamad Amin, } \\
\text { Umie Lestari (Pengembangan Buku } \\
\text { Ajar Evolusi Berbasis Penelitian Untuk } \\
\text { Mahasiswa S1 Pendidikan Biologi } \\
\text { Universitas Jember/ The Development } \\
\text { of Evolution Research-based Module } \\
\text { for Biology Education Undergraduate } \\
\text { Students of Universitas Jember) Jurnal } \\
\text { Pendidikan }\end{array}$ & $\begin{array}{l}\text { Research- } \\
\text { based }\end{array}$ & $\begin{array}{l}\text { The use of molecular } \\
\text { data analysis in } \\
\text { evolution }\end{array}$ & Dick and Carey \\
\hline 2018 & $\begin{array}{l}\text { Nanda Hilda Khikmawati1, Mohamad } \\
\text { Amin, Endang Suarsini (Buku Ajar } \\
\text { Berbasis Penelitian In Silico pada } \\
\text { Matakuliah Teknik Analisis Biologi } \\
\text { Molekuler untuk Mahasiswa Strata } 1 \\
\text { Biologi / In Silico Research-based } \\
\text { Module of Molecular Biology Analysis } \\
\text { Techniques Course for Biology } \\
\text { Undergraduate Students) Jurnal } \\
\text { Pendidikan }\end{array}$ & $\begin{array}{l}\text { Research- } \\
\text { based }\end{array}$ & Molecular Biology & ADDIE \\
\hline 2018 & $\begin{array}{l}\text { Nurul Hidayah Nasution, Fauziyah } \\
\text { Harahap , Tumiur Gultom (The } \\
\text { Development of Tissue Culture } \\
\text { Textbook on Callus Induction of } \\
\text { Mangosteen (Garcinia mangostana L.) } \\
\text { Based on Research) Prosiding Atlantis } \\
\text { Press }\end{array}$ & $\begin{array}{l}\text { Research- } \\
\text { based }\end{array}$ & Tissue Culture & $\begin{array}{l}\text { Thiagarajan } \\
\text { (4D) }\end{array}$ \\
\hline
\end{tabular}

\subsection{Inquiry-based modules}

Each student has different initial preparations prior to conducting activities in the laboratory. Therefore, the guided inquiry activities in the module aim to maximize the development of students' skills (Blumer \& Beck, 2019).

\subsection{Quantitative skills-based modules}

There is a discrepancy between the expected skills that should be acquired by graduates and the real outcome. Therefore, it is important to develop skills-based modules. The types of skill required by Biology graduates are identified to develop a module for students. This skills-based module is expected to be able to teach students various skills needed in the real world to increase students' confidence (Robinson \& McDonald, 2014).

Biology students generally have quantitative problem-solving skills. Thus, a module that facilitates the development of quantitative skills is needed (Hoffman, Leupen, Dowell, Kephart, \& Leips, 2016; Robeva, Davies, Hodge, \& Enyedi, 2010; Thompson et al., 2010).

\subsection{Traditionally-based modules}

Laboratory modules that are traditionally designed are generally like "cookbooks" and are often used as an 
indicator of how well students can follow procedures with little regard for conceptual and procedural understanding of inquiry (Brownell, Kloser, Fukami, \& Shavelson, 2012).

\section{Module topics}

The biology topics found in the review are Genetics, Ecology, Phylogenetics, Biochemistry, Molecular Biology, Evolution, Biotechnology, and Tissue Culture. The materials that require mathematical skills such as molecular biology, ecology, evolution, and phylogenetic use modules that are designed based on quantitative skills. On the other hand, the materials that require the use of informatics technology such as gen bank use bioinformatics module design to support laboratory activities (Alaie et al., 2012). Genetics topics in cross probabilities require an interactive animation learning so that web-based module is used (Thompson et al., 2010). Ecology consists of a variety of natural phenomena that can be used as learning materials so that it is used as one of the topics for problem-based modules (Hewitt et al., 2014) and inquiry-based modules (Blumer \& Beck, 2019).

In general, research topics that produce good data can be used as learning materials in the relevant fields. Thus, it is possible to use research results as materials for creating modules. Based on the review, research-based materials for Biology students in Indonesia that have been identified by the researchers include: Biotechnology (Fitriyati, Mufti, \& Lestari, 2015; Wasiatus, Suarsini, \& Ibrohim, 2016), Molecular Biology (Fadilah, Amin, \& Lestari, 2016; Khikmawati, Amin, \& Suarsini, 2018), Tissue Culture (Nasution, Harahap, \& Gultom, 2018), and the topics for researchbased modules in the international journals include: ecology (Blumer \& Beck, 2019; Brownell et al., 2012), biotechnology (Weber, 2017), molecular biology (Bhatt \& Challa, 2018), dan biochemistry (Hammerstad, Røhr, \& Hersleth, 2019).

\section{Students competencies trained through modules}

Student interest in laboratory activity is able to encourage active participation in order to achieve the competency goals that have been set during learning. Overall, the competencies expected to acquire by Biology students from the innovation of laboratory module design include: understanding and reinforcing concepts/ knowledge, scientific reasoning, quantitative skills, science process skills (formulating hypotheses, designing project, analyzing data, and communicating results in verbal and written form), thinking skills (literacy skills, critical and creative thinking skills), laboratory skills (performance, research skills, research concepts, students' perceptions of their learning experience).

Online or web-based modules that combine biological concepts with mathematical concepts have proven that students have an interest in the material being studied. The use of online-based modules is considered fun for students because they can check whether their understanding of a concept is wrong or right instead of just reading a physical textbook. In addition, the use of web-based modules is expected to improve students' abilities in calculating probabilities, using graphs, and mathematical concepts in biology (Thompson et al., 2010).

The bioinformatics module helps students store information they are learning so that they are able to apply the knowledge well later, even one week after using the module. The quantitative skills-based modules can improve skills in data interpretation, drawing conclusions, and numeracy (Hoffman et al., 2016).

The research-based laboratory module trains students to design experiments, including determining variables that can lead to designing a project to find a methodology that is widely used. Students' interest in research-based modules is caused by activities that provide direct experience in discovering new facts from their own research. Research-based module is a form of innovation in improving the quality of teaching materials because the available materials in the textbooks are not sufficiently contextual and applicative (Rohmani, Amin, \& Lestari, 2017). Modules that are developed based on the results of research are able to create meaningful learning as the materials presented are contextual, deeper, and more interesting. Not only theories or concepts but also scientifically proven facts are presented (Wahyuni, Kiswardianta, \& Yuhanna, 2018).

Similar to other innovative modules, the research problem-based laboratory modules are also able to increase the interest of biology students to actively take part in laboratory research activities. The content of the module can also challenge students' intelligence for a wider mindset (Hewitt et al., 2014). 


\section{Module development approach}

Researchers in Indonesia generally develop modules using approaches that tend to be the same, such as 4D, ADDIE, Dick \& Carey, and Borg \& Gall. In contrast, based on the review on international research publications related to module development, the approach or development model used is not clearly stated. Each development approach has different characteristics in the stages. The differences of the development stages are presented in Table 3 (international researchers) and Table 4 (Indonesian researchers).

The module development model presented in Table 4 generally has the same goal, producing an empirically tested module. The core stages of the four models begin with identifying problems, continue with designing the required module, testing and repairing the module, and end with implementing the module. Development research requires various types of data, data sources, and data analysis methods that vary depending on the needs of researchers.

Table 3. Findings of research approaches used by international researchers in developing undergraduate biology laboratory modules

\begin{tabular}{|c|c|c|c|c|}
\hline $\begin{array}{l}\text { Types of } \\
\text { biology } \\
\text { laboratory } \\
\text { module }\end{array}$ & $\begin{array}{c}\text { Research } \\
\text { methods used }\end{array}$ & Findings & Strengths & $\begin{array}{l}\text { Researchers' } \\
\text { recommendation }\end{array}$ \\
\hline $\begin{array}{l}\text { Online-based } \\
\text { (quantitative } \\
\text { approach) }\end{array}$ & $\begin{array}{l}\text { Analyzing the } \\
\text { need of mastering } \\
\text { mathematical } \\
\text { concepts in } \\
\text { biology } \rightarrow \\
\text { determining } \\
\text { concept } \rightarrow \\
\text { designing module } \\
\rightarrow \text { implementing } \\
\text { module } \rightarrow \\
\text { quantitative skills } \\
\text { assessment from } \\
\text { pretest-posttest } \\
\text { and survey } \\
\text { response of the } \\
\text { module }\end{array}$ & $\begin{array}{l}\text { 55\%: text and } \\
\text { interactive online- } \\
\text { based modules } \\
\text { complement each } \\
\text { other well, } \\
\text { 39\%: prefer module } \\
\text { 6\%: prefer textbook } \\
\text { because web-based } \\
\text { module is } \\
\text { considered } \\
\text { complicated }\end{array}$ & $\begin{array}{l}\text { Interactive, more fun } \\
\text { with a variety of } \\
\text { colorful images, and } \\
\text { not boring. }\end{array}$ & $\begin{array}{l}\text { Increasing the level } \\
\text { of interactivity, such } \\
\text { as: interactive } \\
\text { feedback when } \\
\text { students make } \\
\text { mistakes, student } \\
\text { flexibility in } \\
\text { operating random } \\
\text { choices in the data } \\
\text { base, and increasing } \\
\text { the number of } \\
\text { respondents with a } \\
\text { broader, more } \\
\text { heterogeneous scale. }\end{array}$ \\
\hline $\begin{array}{l}\text { Quantitative } \\
\text { skills-based }\end{array}$ & $\begin{array}{l}\text { Analyzing the } \\
\text { need of } \\
\text { understanding the } \\
\text { integration of } \\
\text { mathematical and } \\
\text { biology concepts } \\
\rightarrow \text { Selecting } \\
\text { various concepts } \\
\text { that can be } \\
\text { developed in } \\
\text { module } \rightarrow \\
\text { designing module } \\
\text { (still in the } \\
\text { development } \\
\text { stage) }\end{array}$ & $\begin{array}{l}\text { Some integration of } \\
\text { mathematical and } \\
\text { biology concepts } \\
\text { that can be } \\
\text { developed in } \\
\text { module: } \\
\text { Mathematical model } \\
\text { in gene regulation } \\
\text { and lac operon } \\
\text { Comparison between } \\
\text { algebra-based and } \\
\text { calculus-based } \\
\text { models on lac } \\
\text { operon } \\
\text { Regulation in } \\
\text { Biochemistry } \\
\text { Role of mathematics } \\
\text { in explaining how } \\
\text { evolution happens } \\
\text { Linear algebraic } \\
\text { approach for } \\
\text { metabolite } \\
\text { Role of Geometry in } \\
\text { reconstruction of } \\
\text { phylogenetic tree } \\
\text { Use of codon and } \\
\text { genome } \\
\text { DNA sequence } \\
\text { analysis }\end{array}$ & $\begin{array}{l}\text { Increasing interest in } \\
\text { integrating modern } \\
\text { mathematics and } \\
\text { biology, increasing } \\
\text { awareness of the } \\
\text { importance of } \\
\text { biomathematics in } \\
\text { life, encouraging } \\
\text { collaboration and } \\
\text { development across } \\
\text { disciplines }\end{array}$ & $\begin{array}{l}\text { Module testing } \\
\text { should be conducted } \\
\text { if the draft module } \\
\text { has been completed } \\
\text { and research-based } \\
\text { applications that can } \\
\text { be used for } \\
\text { mathematics and } \\
\text { biology curriculum } \\
\text { should be provided }\end{array}$ \\
\hline
\end{tabular}




\begin{tabular}{|c|c|c|c|c|}
\hline $\begin{array}{l}\text { Research- } \\
\text { based }\end{array}$ & $\begin{array}{l}\text { Analyzing the } \\
\text { importance of } \\
\text { novelty of the } \\
\text { materials that } \\
\text { need to be } \\
\text { developed in the } \\
\text { laboratory } \\
\text { module } \rightarrow \\
\text { determining pure } \\
\text { research } \\
\text { methods } \rightarrow \text { doing } \\
\text { pure research and } \\
\text { discovering } \\
\text { findings } \rightarrow \\
\text { designing module } \\
\rightarrow \text { implementing } \\
\text { module } \rightarrow \text { conduct } \\
\text { survey response } \\
\text { from students }\end{array}$ & $\begin{array}{l}\text { Better than } \\
\text { traditional module in } \\
\text { improving students' } \\
\text { skills, self- } \\
\text { confidence, and } \\
\text { understanding of } \\
\text { concepts in biology }\end{array}$ & $\begin{array}{l}\text { Students can do } \\
\text { guided inquiry with } \\
\text { open questions } \\
\text { Students can analyze } \\
\text { data and draw } \\
\text { conclusions which } \\
\text { are self-proven } \\
\text { Students can } \\
\text { undertake elements } \\
\text { of scientific research } \\
\text { independently } \\
\text { Stimulating student } \\
\text { interest in } \\
\text { conducting biology } \\
\text { research and } \\
\text { encouraging } \\
\text { participation in } \\
\text { future research } \\
\text { Developing critical } \\
\text { thinking skills in } \\
\text { biology research } \\
\text { which can be } \\
\text { recommended to } \\
\text { other researchers } \\
\text { Students can } \\
\text { experience success } \\
\text { and failure in doing } \\
\text { laboratory research } \\
\text { Students will } \\
\text { experience success } \\
\text { and challenges for } \\
\text { collaborative } \\
\text { research } \\
\text { Students can } \\
\text { communicate the } \\
\text { results in a discipline } \\
\text { manner using } \\
\text { various media. }\end{array}$ & $\begin{array}{l}\text { Research-based } \\
\text { module development } \\
\text { needs to be } \\
\text { conducted } \\
\text { periodically and } \\
\text { continuously as an } \\
\text { effort to update } \\
\text { information. }\end{array}$ \\
\hline $\begin{array}{l}\text { Guided } \\
\text { inquiry- } \\
\text { based }\end{array}$ & $\begin{array}{l}\text { Comparing } \\
\text { students' } \\
\text { readiness in using } \\
\text { the available } \\
\text { inquiry-based } \\
\text { module }\end{array}$ & $\begin{array}{l}\text { In general, there is } \\
\text { no significant } \\
\text { difference between } \\
\text { the use of modules } \\
\text { on students' } \\
\text { scientific reasoning } \\
\text { skills and } \\
\text { experimental design } \\
\text { skills although } \\
\text { students' learning } \\
\text { readiness is different }\end{array}$ & $\begin{array}{l}\text { Providing modern } \\
\text { biology research } \\
\text { experience at } \\
\text { undergraduate level } \\
\text { with inquiry-based } \\
\text { module, preparing } \\
\text { students effectively } \\
\text { to do future work } \\
\text { independently }\end{array}$ & $\begin{array}{l}\text { Conducting further } \\
\text { research to see the } \\
\text { significance of } \\
\text { intervention on } \\
\text { different students' } \\
\text { readiness separately }\end{array}$ \\
\hline $\begin{array}{l}\text { Traditionally- } \\
\text { based }\end{array}$ & $\begin{array}{l}\text { The study was } \\
\text { conducted to } \\
\text { compare the } \\
\text { control class } \\
\text { which was given a } \\
\text { traditional module } \\
\text { with the } \\
\text { experiment class } \\
\text { which used a } \\
\text { research-based } \\
\text { module. Mixed } \\
\text { methods were } \\
\text { used: student } \\
\text { survey, classroom } \\
\text { observation, and } \\
\text { interview }\end{array}$ & $\begin{array}{l}\text { The modules contain } \\
\text { complete materials } \\
\text { and procedures that } \\
\text { must be followed so } \\
\text { that students do not } \\
\text { seem to develop } \\
\text { confidence in doing } \\
\text { laboratory work. }\end{array}$ & $\begin{array}{l}\text { The traditionally- } \\
\text { based module is } \\
\text { used for particular } \\
\text { objectives such as: } \\
\text { Knowing how well } \\
\text { students follow } \\
\text { research instructions } \\
\text { Presenting a general } \\
\text { overview of theory or } \\
\text { specific model } \\
\text { Introducing research } \\
\text { methodology to } \\
\text { conduct research } \\
\text { structurally and } \\
\text { properly. } \\
\text { Training students to } \\
\text { write scientifically } \\
\text { using general } \\
\text { framework }\end{array}$ & $\begin{array}{l}\text { Other types of } \\
\text { modules can be } \\
\text { used, such as } \\
\text { research-based } \\
\text { module which can } \\
\text { better increase } \\
\text { student interest, } \\
\text { scientific attitude, } \\
\text { confidence in } \\
\text { conducting } \\
\text { laboratory research }\end{array}$ \\
\hline
\end{tabular}


On the other hand, the international researchers generally develop modules by analyzing the need of module which tends to focus on the novelty of concepts that is necessary to be developed. The next stages are designing modules, implementing modules, and conducting a periodic and extensive survey from students as the module users.

The most common module design found in the review is research-based module. Review of some literature shows that research-based modules have improved the quality of research activities and the competence of Biology students in Indonesia. The strengths of research-based modules are (1) providing accurate, up-todate and sustainable information and data, (2) providing and creating independent student learning conditions (Sanjaya, Kiswardianta, \& Pujiati, 2017), (3) module content is better because it is made based on research and able to provide students more opportunity to increase participation (Kartikasari, Sulistyarsi, \& Pujiati, 2017), (4) learning more through direct experience, (5) obtaining skills, (6) students can independently assess the results of the work that has been done, and (7) increasing students' independence and confidence in learning (Fitriyati et al., 2015).

Table 3 shows that different types of laboratory module designs that have been developed have their own strengths depending on the concept presented. For example, the concept in the field of bioinformatics has the following learning objectives: (1) train students to have biological computing and bioinformatics skills (2) motivate students to develop an interest in answering biology questions using bioinformatics approach, and (3) enable students to appreciate the use of bioinformatics in the field of modern biology (Madlung, 2018). The use of bioinformatics content in the module can assist researchers in analyzing data to solve research problems (Barone, Williams, \& Micklos, 2017; Madlung, 2018). Another example is inquiry-based modules that show effectiveness in improving scientific reasoning skills and experimental design skills of students who have low initial ability (Blumer \& Beck, 2019).

Table 4. Review of the literature regarding different approaches used for module development by Indonesian researchers

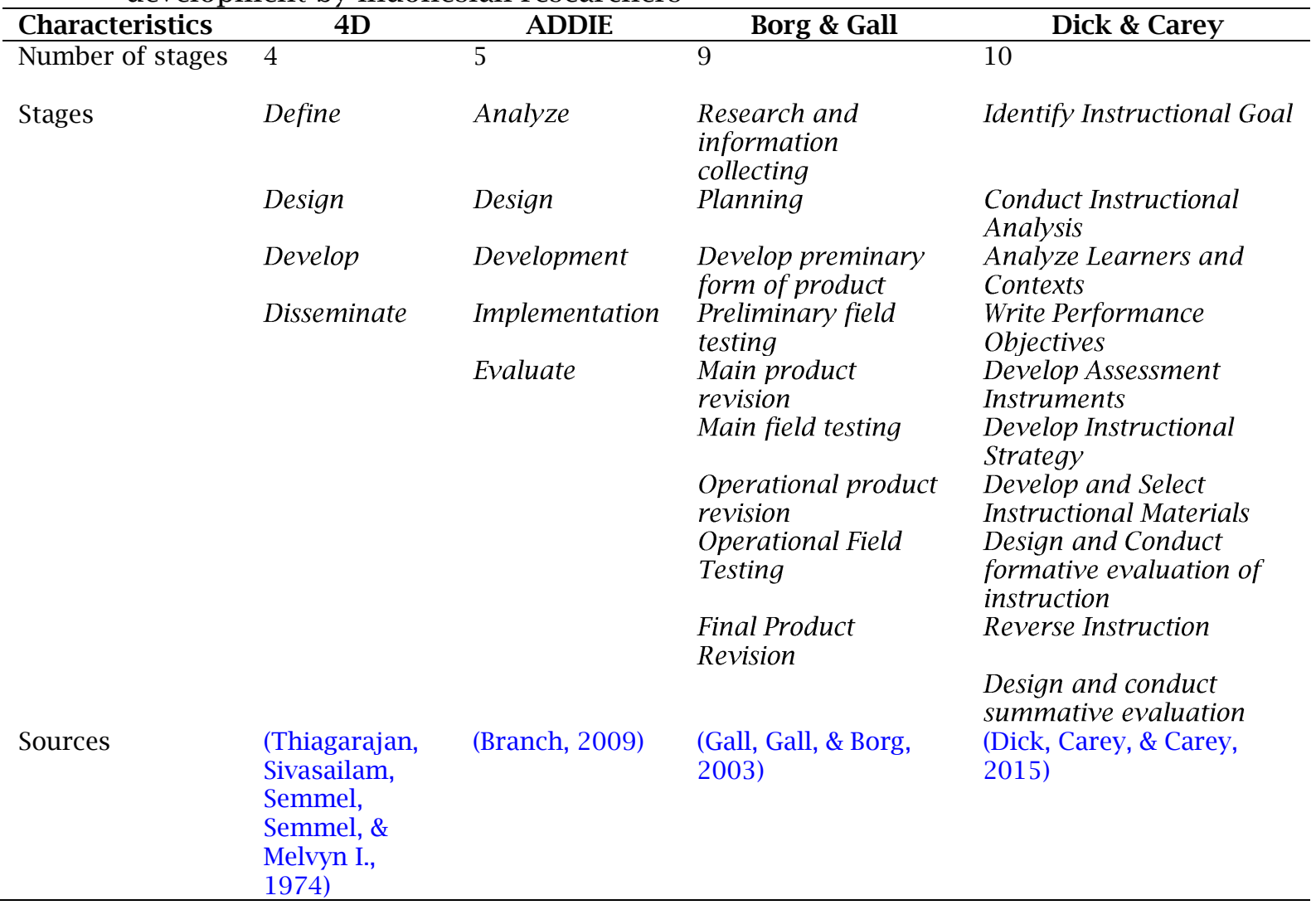

The use of the right type of module will also be able to improve students' Science
Process Skills (SPS). This will benefit students in solving problems, both in the 
laboratory and in everyday life. The effort to improve students' SPS can be started by improving the quality of SPS through the development of teaching materials, such as modules that will later be presented by teachers to facilitate students in doing experiment or exploration activities (Sukarno, Permanasari, \& Hamidah, 2013).

The review results show that it is important to study and develop the design of laboratory modules used for experiment activities and that the traditional modules or existing modules need improvement. Therefore, the results of this study can be used as a reference about Biology student laboratory module designs that have been developed by researchers to provide insights for other researchers.

\section{Conclusion}

There are five types of laboratory module designs that were identified by the researchers. Overall, various innovations in module development for biology students that have been carried out show a better impact on biology students' laboratory skills. The research results on the implementation of modules for biology students can be used as a reference for other researchers to improve other innovative modules. Students' interest in the development of laboratory modules with varied materials shows that the development of laboratory modules for students needs to be continually reviewed to obtain new ideas in developing modules for other materials that are not yet available and complementing the modules with assessment instrument to measure laboratory skills.

\section{Acknowledgment}

This research is a part of a research funded through a Post-Graduate Research Grant Scheme from Universitas Sebelas Maret in 2018-2019, with contract number 516/UN27.21/PP/2019.

\section{References}

Alaie, A., Teller, V., \& Qiu, W. (2012). A bioinformatics module for use in an introductory biology laboratory. The American Biology Teacher, 74(5),
318-322. https://doi.org/10.1525/ abt.2012.74.5.6

Barone, L., Williams, J., \& Micklos, D. (2017). Unmet needs for analyzing biological big data: A survey of 704 NSF principal investigators. PLOS Computational Biology, 13(10), e1005755. https://doi.org/10.1371 /journal.pcbi.1005755

Bhatt, J. M., \& Challa, A. K. (2018). First year course-based undergraduate research experience (CURE) using the CRISPR/Cas9 genome engineering technology in zebrafish †. Journal of Microbiology \& Biology Education, 19(1), 1-9. https://doi. org/10.1128/jmbe.v19i1.1245

Blumer, L. S., \& Beck, C. W. (2019). Laboratory courses with guidedinquiry modules improve scientific reasoning and experimental design skills for the least-prepared undergraduate students. CBE-Life Sciences Education, 18(1), ar2. https://doi.org/10.1187/cbe.18-080152

Branch, R. M. (2009). Instructional design: The ADDIE approach. New York: Springer Science \& Business Media.

Brownell, S. E., Kloser, M. J., Fukami, T., \& Shavelson, R. (2012). Undergraduate biology lab courses: Comparing the impact of traditionally base "Cookbook" and authentic research based courses on student lab experiences. Journal of College Science Teaching, 41(4), 36-45. Retrieved from https:// d1wqtxts1xzle7.cloudfront.net/307 40977/

Dick, W., Carey, L., \& Carey, J. O. (2015). The systematic program of instruction (8th ed.). New Jersey: Pearson Publisher.

Fadilah, R. E., Amin, M., \& Lestari, U. (2016). Pengembangan buku ajar evolusi berbasis penelitian untuk mahasiswa S1 pendidikan biologi Universitas Jember. Jurnal Pendidikan, 1(6), 1104-1109. Retrieved from http://journal.um. ac.id/index.php/jptpp/article/view/ 6425

Fajarwati, L. P., Kiswandianta, R. B., \& Pujiati. (2018). Penyusunan modul mikrobiologi bebrbasis penelitian purifikasi dan uji aktivasi enzim 
selulase dari Kapang Trichoderma viride. Prosiding Seminar Nasional SIMBIOSIS, 217-224. Retrieved from http://prosiding.unipma.ac.id/inde x.php/simbiosis/article/view/661

Fitriyati, U., Mufti, N., \& Lestari, U. (2015). Pengembangan modul berbasis riset pada matakuliah Bioteknologi. Jurnal Pendidikan Sains, 3(3), 118129. Retrieved from http://journal. um.ac.id/index.php/jps/article/vie $\mathrm{w} / 7995$

Gall, M. D., Gall, J. P., \& Borg, W. R. (2003). Educational research: An introduction (7th ed.). United States of America: Allyn and Bacon.

Goff, E. E., Reindl, K. M., Johnson, C., McClean, P., Offerdahl, E. G., Schroeder, N. L., \& White, A. R. (2017). Efficacy of a meiosis learning module developed for the virtual cell animation collection. CBE-Life Sciences Education, 16(1), ar9. https://doi.org/10.1187/cbe.16-030141

Hammerstad, M., Røhr, Å. K., \& Hersleth, H. (2019). A research-inspired biochemistry laboratory modulecombining expression, purification, crystallization, structure-solving, and characterization of a flavodoxin-like protein. Biochemistry and Molecular Biology Education, 47(3), 318-332. https://doi.org/10. 1002/bmb.21218

Hewitt, K. M., Kayes, L. J., Hubert, D., \& Chouinard, A. (2014). Investigating issues in the laboratory. The American Biology Teacher, 76(9), 609-614. https://doi.org/10.1525/ abt.2014.76.9.7

Hoffman, K., Leupen, S., Dowell, K., Kephart, K., \& Leips, J. (2016). Development and assessment of modules to integrate quantitative skills in introductory biology courses. $C B E-$ Life Sciences Education, 15(2), ar14. https://doi.org/10.1187/cbe.15-090186

Howard, D. R., \& Miskowski, J. A. (2005). Using a module-based laboratory to incorporate inquiry into a large cell biology course. Cell Biology Education, 4(3), 249-260. https://doi.org/10.1187/cbe.04-090052
Kartikasari, E., Sulistyarsi, A., \& Pujiati. (2017). Penyusunan modul eubacteria untuk biologi SMA kelas $\mathrm{x}$ melalui isolasi dan karakterisasi bakteri selulolitik pada tanah kebun teh jamus ngawi jawa timur. Prosiding Seminar Nasional SIMBIOSIS, 368-377. Retrieved from http://prosiding.unipma.ac.id/inde x.php/simbiosis/article/view/353

Khan, K. S., Kunz, R., Kleijnen, J., \& Antes, G. (2003). Five steps to conducting a systematic review. Journal of the Royal Society of Medicine, 96(3), 118121. https://doi.org/10.1177/0141 07680309600304

Khikmawati, N. H., Amin, M., \& Suarsini, E. (2018). Buku ajar berbasis penelitian in silico pada matakuliah teknik analisis biologi molekuler untuk mahasiswa strata 1 biologi. Jurnal Pendidikan, 3(9), 1184-1189. Retrieved from http://journal. um.ac.id/index.php/jptpp/article/vi ew/11548

Madlung, A. (2018). Assessing an effective undergraduate module teaching applied bioinformatics to biology students. PLOS Computational Biology, 14(1), e1005872. https://doi.org/10.1371/journal.pc bi. 1005872

Nasution, N. H., Harahap, F., \& Gultom, T. (2018). The development of tissue culture textbook on callus induction of Mangosteen (Garcinia mangostana L.) based on research. Proceedings of the 3rd Annual International Seminar on Transformative Education and Educational Leadership (AISTEEL 2018), 200, 655-658. https://doi. org/10.2991/aisteel-18.2018.143

Peteroy-Kelly, M. (2010). Online prelaboratory modules enhance introductory biology students' preparedness and performance in the laboratory. Journal of Microbiology \& Biology Education, 11(1), 1-15. https://doi.org/10.1128 /jmbe.v11.i1.130

Robeva, R., Davies, R., Hodge, T., \& Enyedi, A. (2010). Mathematical biology modules based on modern molecular biology and modern discrete mathematics. CBE-Life Sciences Education, 9(3), 227-240. 
https://doi.org/10.1187/cbe.10-030019

Robinson, R. L., \& McDonald, J. E. (2014). Developing skills in second year biological science undergraduates. Bioscience Education, 22(1), 42-53. https://doi.org/10.11120/beej.2014 .00026

Rohmani, M., Amin, M., \& Lestari, U. (2017). Analisis kebutuhan bahan ajar berbasis penelitian materi bioteknologi bidang kedokteran untuk mahasiswa S1 pendidikan biologi Universitas Negeri Malang berdasarkan model pengembangan ADDIE. Seminar Nasional Pendidikan IPA, 496-501. Retrieved from http://pasca.um.ac.id/conferences/i ndex.php/ipa2017/article/view/109 1

Sanjaya, F. M., Kiswardianta, R. B., \& Pujiati. (2017). Penyusunan modul zat pengawet makanan kelas viii smp berbasis penelitian zat antibakteri. Prosiding Seminar Nasional SIMBIOSIS II, 310-314. Retrieved from http://prosiding.unipma.ac.id/ index.php/simbiosis/article/view/3 46

Siritunga, D., Montero-Rojas, M., Carrero, K., Toro, G., Vélez, A., \& CarreroMartínez, F. A. (2011). Culturally relevant inquiry-based laboratory module implementations in upperdivision genetics and cell biology teaching laboratories. CBE-Life Sciences Education, 10(3), 287-297. https://doi.org/10.1187/cbe.11-040035

Sukarno, Permanasari, A., \& Hamidah, I. (2013). The Profile of Science Process Skill ( SPS ) Student at Secondary High School ( Case Study in Jambi ). International Journal of
Scientific Engineering and Research (IJSER), 1(1), 79-83.

Thiagarajan, Sivasailam, Semmel, Semmel, D. S. \&, \& Melvyn I. (1974). Instructional Development for Training Teachers of Exceptional Children. Bloomington: Indiana University.

Thompson, K. V, Nelson, K. C., Marbach-Ad, G., Keller, M., \& Fagan, W. F. (2010). Online interactive teaching modules enhance quantitative proficiency of introductory biology students. CBE-Life Sciences Education, 9(3), 277-283. https://doi.org/10.1187/ cbe.10-03-0028

Wahyuni, H., Kiswardianta, R. B., \& Yuhanna, W. L. (2018). Pengembangan modul berbasis riset pada mata kuliah anatomi tumbuhan. Prosiding Seminar Nasional SIMBIOSIS III, 3643. Retrieved from http://prosiding. unipma.ac.id/index.php/simbiosis/ article/view/636

Wasiatus, S., Suarsini, E., \& Ibrohim. (2016). Pengembangan modul bioteknologi lingkungan berbasis penelitian matakuliah bioteknologi untuk mahasiswa S1 Universitas Negeri Malang. Jurnal Pendidikan, 1(9), 1781-1786. Retrieved from http://journal.

um.ac.id/index.php/jptpp/article/vi ew/6830

Weber, C. F. (2017). Microgreen farming and nutrition: A discovery-based laboratory module to cultivate biological and information literacy in undergraduates. The American Biology Teacher, 79(5), 375-386. https://doi.

org/10.1525/abt.2017.79.5.375 